\title{
MEDIA PEMBELAJARAN BAHASA ARAB
}

\author{
Siti Mahmuda \\ SD Muhammadiyah Metro \\ E-mail: sitimahmudah13@yahoo.com
}

\begin{abstract}
الملخص

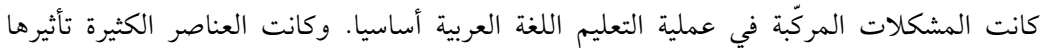

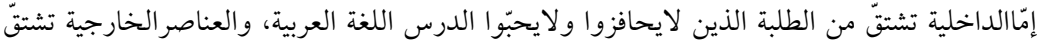

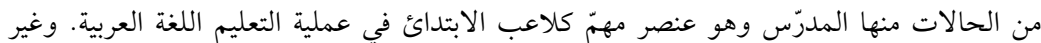

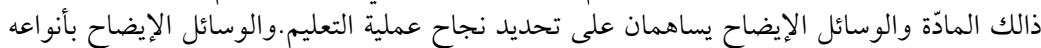

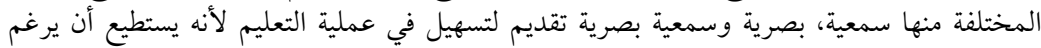

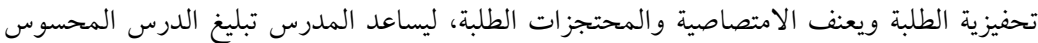

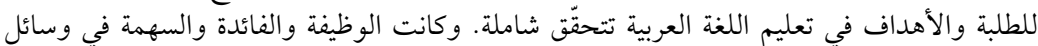

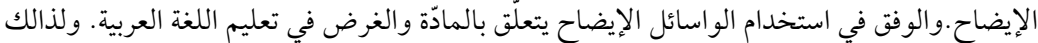

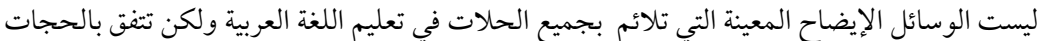

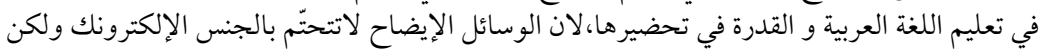

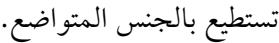

\begin{abstract}
Abstrak
Pada dasarnya proses belajar mengajar bahasa Arab memiliki masalah yang komplek. Banyak faktor yang mempengaruhinya, baik secara interen maupun eksteren. Faktor intern berasal dari diri siswa, kebanyakan dari para siswa kurang termotivasi dalam belajar bahasa Arab dan bahkan banyak siswa yang juga tidak menyenangi pelajaran bahasa Arab. Sedangkan faktor eksteren berasal dari beberapa hal, guru menjadi salah satu faktor penting sebagai pemeran utama dalam proses pembelajaran. Selain itu sumber belajar dan media pembelajaran juga berperan dalam menentukan keberhasilan proses pembelajaran. Media pembelajaran dengan berbagai macam bentuknya baik berupa audio, visual maupun audio visual hadir untuk mempermudah proses belajar mengajar bahasa Arab karena dapat mendorong
\end{abstract}


motivasi belajar siswa, dapat mempertinggi daya serap dan retensi siswa terhadap materi pelajaran, sehingga membantu para pengajar dalam menyampaikan materi yang bisa lebih konkrit diterima siswa sehingga tujuan pembelajaran bahasa Arab dapat tercapai secara maksimal. Media pembelajaran mempunyai fungsi, kegunaan dan peranan yang komplek dalam pembelajaran bahasa Arab. Cocok atau tidaknya penggunaan media tertentu dalam pembelajaran bergantung pada tujuan dan materi pembelajaran . Sehingga tidak ada media tertentu yang terbaik dan cocok untuk segala situasi dan kondisi pembelajaran, namun media yang cocok adalah media yang sesuai dengan kebutuhan pembelajaran dan ketersediaan media itu sendiri dalam sebuah lembaga pendidikan, karena penggunaan media pembelajaran tidak harus yang berjenis elektronik tetapi juga bisa berbentuk media sederhana yang ada.

Kata Kunci: Fungsi, kegunaan, peran, media pembelajaran

\section{A. Pendahuluan}

Pada hakikatnya proses belajar mengajar adalah proses komunikasi. Dalam proses komunikasi tersebut terdapat tiga komponen penting yang memainkan perannya yaitu; pesan yang disampaikan dalam hal ini adalah kurikulum, guru sebagai komunikator, dan siswa sebagai komunikasinya. Agar proses komunikasi berjalan dengan lancar atau berlangsung secara efektif dan efisien diperlukan alat bantu yang disebut dengan media pembelajaran. ${ }^{1}$

Istilah media pembelajaran memiliki beberapa pengertian. Salah satu pendapat memberikan pengertian media secara luas dan secara sempit. Adapun secara luas media pembelajaran dimaknai sebagai setiap orang, materi, atau peristiwa yang memberikan kesempatan kepada siswa untuk memperoleh pengetahuan, keterampilan dan sikap. Adapun pengertian secara sempit yang dimaksud dengan media pembelajaran adalah sarana non personal ( bukan manusia) yang digunakan oleh guru yang memegang peranan dalam proses belajar mengajar untuk menacapai tujuan. Dengan demikian pengertian tersebut cenderung menganggap wujud media adalah alat-alat grafis atau elektronik untuk menangkap, menyusun kembli informasi visual atau verbal. ${ }^{2}$

Abd. Wahab Rosyidi, Mamlu'atul Ni'mah, Memahami Konsep Dasar Pembelajaran Bahasa Arab, (malang: UIN-Maliki Press, 2012), h. 101

Ibid, h. 101-102 
Pengertian lain dikemukakan bahwa media pembelajaran meliputi alat yang secara fisik digunkan untuk menyampaikan isi materi pengajaran yang diantaranya terdiri dari buku, tape recorder, kaset, video camera, video recorder, film, slide, foto, gambar, grafik, televisi dan komputer. Dengan kata lain, media adalah komponen sumber belajar atau peralatan fisik yang mengandung materi pembelajaran di lingkungan siswa yang dapat merangsang siswa untuk belajar. Selain pendapat di atas media pembelajaran juga artikan sebagai perpaduan dari perangkat keras (hardware) dan perangkat lunak (software). Dengan kata lain media adalah hardware yang telah diisi dengan perangkat lunak software. ${ }^{3}$

Dari pendapat diatas dapat kita fahami bahwa media pembelajaran dapat berupa banyak hal. Dari hal yang paling sederhana dan dekat dengan kita misalkan guru itu sendiri, buku ajar, papan tulis dan lain sebagainya, sampai pada hal yang bersifat pengembangan seperti media dari perangkat keras (hardware) atau perangkat lunak (software) sesuai dengan perkembangan teknologi saat ini. Dalam hal ini, yang paling urgen adalah keterampilan guru dalam pemanfaatan media dalam bentuk apapun sebagai sarana penunjang dalam keberhasilan proses belajar mengajar.

Media pengajaran berperan penting dalam pembelajaran bahasa asing, termasuk untuk pembelajaran bahasa Arab. Media pembelajaran bukan saja baik untuk pembelajar anak-anak tetapi juga untuk pembelajar dewasa. Telah banyak penelitian yang membuktikan keefektifan penggunaan media dalam pembelajaran bahasa asing (Arab), sayangnya tidak banyak guru yang menggunakan media pembelajaran sebagai salah satu unsur penunjang proses pembelajaran bahasa (Arab), salah satu diantaranya adalah karena menurut guru, penyediaan media pembelajaran membutuhkan biaya yang banyak dan waktu yang cukup panjang. Dalam hal ini guru tidak mau banyak mengambil resiko, sehingga pembelajaran bahasa menjadikan siswa cepat mengalami kebosanan. ${ }^{4}$

Media pembelajaran juga merupakan salah satu unsur yang penting dan harus dipenuhi dalam proses pembelajaran. Sebagaimana dijelaskan Abdurochman bahwa: “Unsur-unsur yang harus dipenuhi dalam pembelajaran adalah sebagai berikut: kurikulum, materi pembelajaran Bahasa Arab, metode pembelajaran bahasa Arab, media pembelajaran,

Abd. Wahab Rosyidi, Media Pembelajaran Bahasa Arab, (Malang: UIN MALANG PRESS, 2009), h. 26

Ibid, h. 20 
tujuan pembelajaran bahasa arab, peserta didik, guru bahasa Arab, evalasi pembelajaran bahasa Arab." ${ }^{5}$

Dewasa ini masih banyak kita jumpai, belum semua guru memanfaatan penggunaan media dalam proses belajar mengajar. Padahal dari beberapa pendapat tentang pengertian media pembelajaran dan pentingnya peranan media dalam proses belajar mengajar, penggunaan media merupakan suatu keharusan. Hal ini, tentu mempunyai banyak faktor penyebab, diantaranya belum meratanya pembangunan dalam bidang pendidikan di Indonesia. Dalam artian masih ada ketimpangan yang sangat besar antara pendidikan di kota dan di desa, baik dari segi sarana prasarana (media dalam berntuk hardware dan software) dan segi kantitas dan kualitas guru, dalam artian karena keterbatasan jumlah pengajar terkadang satu orang guru di sekolah -sekolah desa bisa mengajar bebarapa mata pelajaran sehingga tidak sesuai dengan bidang keilmuan dan tentu kondisi seperti ini menjadi salah satu penyebab tidak terampilnya seorang guru dalam memanfaatkan media pembelajaran bahkan dari yang paling sederhana, misalkan penggunaan kartu mufradat dan lain sebagainya. Dari segi kualitas guru yang ada di sekolah-sekolah perkotaan ditunjang oleh berbagai sarana sebagai pengembang keprofesionalan dalam mengajar, misalnya mengikuti seminar pendidikan, workshop dan lain sebagainya, yang hal ini tidak banyak didapatkan oleh guru yang mengajar di pedesaan. Namun di era saat ini, dengan teknologi yang semakin canggih dan jaringan internet yang mampu menembus keseluruh lapisan, seharusnya hal ini tidak lagi menjadi persoalan yang berarti. Dengan memanfaatkan gadget atau handphone, seorang guru dapat mencari informasi dalam bentuk apapun termasuk pemanfaatan media dalam pembelajaran.

\section{B. Fungsi, Kegunaan, dan Peran Media Pembelajaran Bahasa Arab}

\section{Fungsi Media Pembelajaran Bahasa Arab}

Dalam proses belajar mengajar, media memiliki fungsi yang sangat penting. Secara umum fungsi media adalah sebagai penyalur pesan. Selain fungsi tersebut penggunaan media dalam proses belajar juga dapat membangkitkan rasa ingin tahu dan minat, membangkitkan motivasi dan rangsangan dalam proses belajar mengajar, serta dapat mempengaruhi

Abdurochman, Bahasa Arab dan Metode Pembelajarannya, (Bandar lampung: AURA, 2017), h. 2 
psikologi siswa. Penggunaan media juga dapat membantu siswa dalam meningkatkan pemahaman, menyajikan materi/ data dengan menarik, memudahkan menafsirkan data, dan memadatkan informasi.

Pendapat lain menjelaskan bahwa media pembelajaran, khususnya media visual memiliki empat fungsi, yaitu fungsi atensi, fungsi afektif, fungsi kognitif, dan fungsii kompensatoris. Fungsi atensi adalah media visual dapat menarik atau mengarahkan perhatian siswa agar dapat berkonsentrasi pada isi pembelajaran yang terkandung dalam media visual tersebut. Fungsi afektif yaitu media fisual dapat digunakan untuk menciptakan rasa senang atau kenikmatan siswa terhadap isi pembelajaran. Fungsi kognitif adalah media visual dapat mempermudah siswa dalam memahami pesan atau informasi yang disampaikandalam pembelajaran. Sedangkann dalam fungsi kompensatoris adalah media visual dapat mengakomodasi siswa lemah dalam menerima isi pembelajaran.

Selain itu fungsi media pembelajaran, khususnya media audio visual, bukan saja sekedar menyalur pesan, melainkan juga membantu menyederhanakan proses penerimaan pesan yang sulit sehingga proses komunikasi menjadi lancar tanpa distorsi. ${ }^{6}$

Pendapat lain menjelaskan bahwa media pembelajaran tersebut dipakai oleh seorang guru untuk:

a. Memperjelas informasi atau pesan pengajaran.

b. Memberi tekanan pada bagian-bagian yang penting.

c. Memberi variasi pengajaran.

d. Memperjelas struktur pengajaran.

e. Memotivasi proses belajar siswa. ${ }^{7}$

Berdasarkan pendapat di atas, media pembelajaran mempunyai fungsi yang sangat penting dalam proses belajar dan hasil belajar siswa. Dengan menggunakan berbagai macam media pembelajaran yang variatif, baik bersifat audio, visual ataupun audio visual, yang tentunya harus disesuaikan dengan kebutuhan materi ajar, akan menumbuhkan motivasi siswa dalam belajar sehingga mereka akan terhindar dari rasa kejenuhan karena pembelajarannya mengasyikkan dan tidak monoton sehingga siswa akan lebih mudah memahami pelajaran dan harapannya akan memberikan 
pengaruh yang positif pada hasil belajar siswa secara kognitif, afegtif ataupun psikomotorik.

\section{Kegunaan Media Pembelajaran}

Secara umum media pembelajaran mempunyai kegunaan-kegunaan sebagai berikut:

a. Memperjelas penyajian pesan agar tidak terlalu bersifat verbalistik (dalam bentuk kata tertulis atau lisan)

b. Mengatasi keterbatasan ruang, waktu dan daya indera seperti:

1. Obyek yang terlalu besar, bisa digantikan dengan realita, gambar, film bingkai, film, atau model.

2. Obyek yang kecil, bias dibantu dengan proyektor mikro, film bingkai, film atau gambar.

3. Gerak yang terlalu lambat atau terlalu cepat, dapat dibantu dengan timelapse atau high-speed photography.

4. Kejadian atau peristiwa yang terjadi di masa lalu bisa ditampilkan lagi lewat rekaman film, video, film bingkai, foto maupun secara verbal.

5. Obyek yang terlalu kompleks dapat disajikan dengan model, diagram, dan lain-lain.

Dengan menggunakan media pembelajaran secara tepat dan bervariasi dapat diatasi sikap pasif peserta didik. Dalam hal ini media pembelajaran berguna untuk:

1. Menimbulkan gairah/ semangat belajar

2. Memungkinkan interaksi yang lebih langsung antara peserta didik dengan lingkungan dan kenyataan.

3. Memungkinkan peserta didik, belajar sendiri-sendiri menurut skemampuan dan minatnya

4. Memudahkan untuk menggali informasiyang dibutuhkan. ${ }^{8}$

Pendapat lain menjelaskan bahwa media pengajaran memilki kegunaan sebagai berikut:

1. Menarik minat siswa

2. Meningkatkan pengertian siswa

3. Memberikan data yang kuat/terpercaya

4. Memadatkan informasi

Abd. Wahab Rosyidi, Op. Cit, h. 30-32 
5. Memudahkan menafsirkan data. ${ }^{9}$

Pendapat lain menjelaskan kegunaan media pembelajaran adalah salah satu kiat dalam menghindari kejenuhan dalam belajar bahasa asing. khususnya media elektronik yang bersifat visual, audio, atau audio visual. ${ }^{10}$

Media pembelajaran memiliki kegunaan yang kompleks. Dimulai dengan proses penggunaannnya hingga pada hasil dari penggunaan media tersebut. Kegunaan media dalam proses pembelajaran sangat penting sekali karena dengan media proses pembelajaran akan bisa berlangsung dengan aktif, kreatif dan efektif dan menyenangkan. Dengan demikian hasil yang dicapai akan lebih maksimal.

\section{Peran Media Pembelajaran bahasa Arab}

Media pengajaran berperan penting dalam pembelajaran bahasa asing, termasuk untuk pembelajaran bahasa Arab. Media pembelajaran bukan saja baik untuk pembelajar anak-anak tetapi juga untuk pembelajar dewasa. Telah banyak penelitian yang membuktikan keefektifan penggunaan media dalam pembelajaran bahasa asing (Arab).

Dalam proses belajar mengajar melibatkan sejumlah komponenyang saling bekerja sama untuk mencapai tujuan. Dan diantara komponen itu adalah guru dan media. Maka media dalam proses belajar mengajar memiliki peran dalam berbagai pola kegiatan tersebut, diantaranya adalah:

1. Guru sebagai sumber belajar sekaligus media

Dalam proses belajar mengajar guru merupakan salah satu yang bertindak sebagai sumber belajar dan media pembelajaran. Dalam menyampaikan materi kepada siswa, seorang guru dituntut mampu menjelaskan dengan bahasa verbal ataupun nonverbal. Sehingga keprofesionalan guru sangat menentukan tingkat efektifitas dan efisiennya.

2. Guru dan Media sebagai sumber belajar

Dalam hal ini guru dan media sama-sama memiliki peran. Dalam menyampaikan materi, guru memanfaatkan media sebagai peraga atau alat bantu yang memperjelas materi yang disampaikan oleh guru

9 Azhar Arsyad, Bahasa Arab dan Metode Pengajarannya,(Yogyakarta: Pustaka Pelajar, 2010), h.75

10 Mukhlish Fuadi, Otomatisasi Harakat Bahasa Arab, (Malang; UIN MALIKI PRESS, 2010), h. s 
kepada siswa. Mislakan media gambar, pesan yang dismpaikan guru kepada siswa diperjelas oleh gambar.

3. Guru menyerahkan sebagian tanggung jawabnya kepada media

Dalam hal ini guru dan media sama -sama memiliki tanggung jawab dalam mengendalikan proses belajar mengajar. Secara otonomi media memiliki peran dalam menyampaikan pesan. Mislkan menggunakan tape recorder dalam menyimak berita. Namun guru harus pandai dalam mengambil kesempatan menjelaskan pesan yang belum tersampaikan atau masih belum jelas dalam media.

4. Media sebagai satu-satunya sumber belajar

Dalam hal ini media sebagai pengendala proses belajar mengajar. Misalkan system belajar jarak jauh. ${ }^{11}$

Media pembelajaran memilki peranan yang sangat penting dalam proses pembelajaran. Diantaranya media sebagai alat yang bisa membantu guru dalam menjelaskan/ menyampaikan pesan/ materi kepada peserta didik, dalam satu waktu guru lah yang menjadi media dalam proses pembelajaran, menjadi model utama yang dilihat dan didengar langsung oleh peserta didik sehingga dalam hal ini kemampuan guru menjadi tolak ukur keberhasilan pembelajaran, dalam kondisi lain adakalanya media lah yang secara otonomi memiliki peran dalam proses belajar mengajar, guru hanya menambahkan penjelasan yang belum tersampaikan dan belum jelas dari medua. Dan yang terakhir media berperan aktif dan sebagai satusatunya sumber belajar.

\section{Simpulan}

Media pembelajaran bahasa Arab memiliki fungsi, kegunaan dan peran yang sangat penting dalam proses belajar mengajar dan dalam pencapaian hasil belajar. Penggunaan media dalam proses belajar menjadi salah satu motivasi bagi siswa dalam belajar. Dengan penggunaan media proses belajar mengajar akan menjadi lebih aktif, afektif dan kreatif. Suasana kelas juga akan terhindar dari kejenuhan dan kebosanan, kerana tidak bersifat monoton. Kemampuan guru dalam memanfaatkan berbagai macam bentuk media juga menentukan keberhasilan dalam belajar.

Berbagai macam bentuk media baik bersifat perangkat keras (hardwere) dan perangkat lunak (softwere), memiliki fungsi, kegunaan 
dan peran masing-masing tergantung dengan kebutuhan materi ajar dan tujuan yang hendak dicapai. Keterbatasan pengadaan media yang berjenis elektronik untuk lembaga pendidikan tertentu bukan menjadi kendala yang berarti, selama guru sebagai sumber belajar dan media pembelajaran utama mampu memanfaatkan media sederhana yang ada. Sehingga proses belajar mengajar dan keberhasilan pembelajaran bahasa Arab dapat dicapai dengan maksimal.

\section{DAFTAR PUSTAKA}

Abd. Wahab Rosyidi, Mamlu'atul Ni'mah, Memahami Konsep Dasar Pembelajaran Bahasa Arab, (malang: UIN-Maliki Press, 2010)

Abd. Wahab Rosyidi, Media Pembelajaran Bahasa Arab, (Malang: UIN MALANG PRESS, 2009)

Abdurochman, Bahasa Arab dan Metode Pembelajarannya, (Bandar lampung: AURA, 2017)

Azhar Arsyad, Bahasa Arab dan Metode Pengajarannya,(Yogyakarta: Pustaka Pelajar, 2010)

Mukhlish Fuadi, Otomatisasi Harakat Bahasa Arab, (Malang; UIN MALIKI PRESS, 2010) 
138 | Siti Mahmuda 